\title{
RELIGION IN THE PUBLIC SPHERE: WHAT CAN PUBLIC THEOLOGY LEARN FROM HABERMAS'S LATEST WORK?
}

Authors:

Jaco S. Dreyer ${ }^{1}$

Hennie J.C. Pieterse

\section{Affiliations: \\ ${ }^{1}$ Department Practical \\ Theology, University of \\ South Africa, South Africa}

\section{Correspondence to: \\ Jaco Dreyer}

email:

dreyejs@unisa.ac.za

Postal address:

PO Box 392, Unisa 0003,

South Africa

\section{Keywords:}

religion; public sphere; public theology;

Habermas; translation

imperative

\section{Dates:}

Received: 02 Mar. 2010

Accepted: 04 Apr. 2010

Published: 18 Oct. 2010

How to cite this article:

Dreyer, J.S. \& Pieterse,

H.J.C., 2010, 'Religion in

the public sphere: What can public theology learn from Habermas's latest work?', HTS Teologiese Studies/Theological Studies 66(1), Art. \# 798, 7 pages. DOI: $10.4102 /$ hts.v66i1.798

\section{Note:}

Hennie J.C. Pieterse is Professor Emeritus in the Department of Practical Theology at the University of South Africa, Pretoria.

This article is available at:

http://www.hts.org.za

(C) 2010. The Authors. Licensee: OpenJournals Publishing. This work is licensed under the Creative Commons Attribution License.

\section{ABSTRACT}

The complex and problematic role of religion in the public sphere in modern, democratic societies raises many questions for a public theology. The aim of this article is to contribute to the ongoing debate about the task and methods of public theology by asking what we can learn from the ideas of Jürgen Habermas. Habermas was a leading participant in the thinking process on the secularisation thesis in Western societies. His view was that religion will eventually disappear from the public scene due to the rationalisation of society. In recent years he seems to have changed this view in the light of new developments in the world. He now maintains that religion has something important to offer in the public sphere. Religion could thus participate in this public discussion, provided that it satisfies strict conditions. We argue that public theology can learn from Habermas's recent ideas regarding religion in the public sphere: attention should be paid to the cognitive potential of religion, especially regarding the importance of the lifeworld and the role of religion in social solidarity with the needy and vulnerable; hermeneutical self-reflection is important; a distinction should be made between the role of religion in faith communities and in public life; we have to accept that we live in a secular state; and we have to learn the possibilities and impossibilities of translating from religious vocabulary into a secular vocabulary in order to be able to participate in the discussions in the public sphere.

\section{INTRODUCTION}

The role of religion in the public sphere is problematic. Religion has lost its taken-for-granted status in society and the public sphere. Charles Taylor (2007), in his monumental work A secular age, gives a cogent description of the withdrawal of a religious worldview from the public sphere and the dawn of a secular age. However, the predictions of secularisation theorists that the only remains of religion may be a totally privatised experience of it by a few (cf. Dekker, Luidens \& Rice 1997), and that religion will be eradicated from public life, have proven to be wrong (Casanova 1994). Modernisation processes have not led to the eradication of religion from public life (Joas 2009). At the end of the first decade of the 21st century we can conclude that the privatisation of religion is not a historical trend or a normative condition for modern, liberal democracies, as once assumed.

Religion and religious issues still form part of the fabric of modern societies. The role of religion, religious themes and religious institutions in recent election campaigns, both in the United States of America (USA) and in South Africa, bear testimony to this continuing presence of religion. There even seems to be a renewal of the traditional bond between religion and nationalism in certain societies, and an increase in the kind of religious expression associated with fundamentalist and national religious expansion through religious communities catering for different racial, ethnic and social identities (Bosch 1991:476; To \& Tulasiewicz 1993:178). Established democracies seem to struggle with this religious plurality in multicultural societies, as multiculturalism and religious diversity often go hand in hand. It is thus commonly accepted that religion has not disappeared from the public sphere.

Although religion still plays a role in the public sphere, the relationship between religion and public life is quite problematic. The debate in France about displaying religious symbols publicly is just one example of the problematic relationship between religion and public life (Mooney 2006:1457). There are many questions regarding the role of religion in the public sphere. Let us look at a few examples: How must we deal with the issue of religious education in public schools? How do we deal with different religious calendars in our business life? How should we view prayers at public gatherings? How do we deal with religious groups' petitions regarding the death penalty, abortion or same-sex marriages? How do we deal with the atheist's claim to freedom from religion? These examples clearly demonstrate the problematic presence of religion in the public sphere.

The role of religion in the public sphere also causes problems for theologians. It is possible, for example, to summarise broad patterns in Protestant theology in reaction to the Enlightenment and the loss of a religious worldview. Generally speaking, orthodoxy clings to its traditional theological positions; Pietism flees from rational criticism of religion to the safe harbour of the subjective religious experiences of the individual; liberal theology tries to reconcile the Christian message with the views of the Enlightenment by digging out the core message of Christianity from the Bible and building hermeneutical bridges for the understanding of the message by modern minds; and political theology accepts the principles of the Enlightenment and tries to show that the Christian faith is in line with this thinking if we understand it as realising the ideals of modern people: liberation from oppressive structures and political oppression, eradication of poverty and restoration of human dignity (cf. Jonker 2008:135-137). There are mixed models of these extreme positions in Protestant theology, but a brief overview of the theological reactions shows the intensity of the theological debate in its efforts to digest the radical cultural changes that have taken place in the church in the past three hundred years. 
One of the tasks of a public theology is to reflect on the role of religion in the public sphere in modern or modernising democratic societies such as South Africa. Public theologians have to reflect on, amongst other things, how to deal with different religious claims in the public sphere. What is the task of a public theology when different religious traditions and communities hold different opinions about public issues, and when competing and conflicting religious claims enter the public sphere? To make it more concrete, what is the role and task of a public theology when we are, for example, confronted by opposing views on marriage, homosexuality, abortion, and so forth?

The complex and problematic role of religion in the public sphere in modern, democratic societies raises many questions for a public theology. The aim of this article is to contribute to the ongoing debate about the task and methods of public theology by asking what we can learn from the ideas of the German social philosopher Jürgen Habermas.

Why do we choose to engage with an agnostic and secular thinker like Habermas? Besides for the fact that theologians have engaged with Habermas's ideas for many years, we put forward two other, important reasons. Firstly, Habermas is one of the most important theorists regarding the public sphere. According to Calhoun (1992:4), Habermas had already expressed his interest in the public sphere as an important domain in modern democracies in a book based on his habilitation qualification ('Habilitationsschrift') Strukturwandel der Öffentlichkeit: Untersuchungen zu einer Kategorie der bürgerlichen Gesellschaft (1962), which was translated into English as The structural transformation of the public sphere: An inquiry into a category of bourgeois society (1989). Secondly, Habermas has in recent years paid much attention to the role and position of religion in the public sphere (Cooke 2006; Harrington 2007a, 2007b; Lafont 2007). This greater openness to religion has surprised many, particularly in the light of his well-known secular and agnostic approach to religion.

What can public theology learn from Habermas's recent work regarding the role and position of religion in the public sphere? In order to answer this question we address the following subquestions: What is the background and context of Habermas's recent views on religion in the public sphere?; How does he view the role of religion in the public sphere in his latest work?; and, What can public theology learn from Habermas's view of the role of religion in the public sphere? The article ends with a brief conclusion.

\section{THE BACKGROUND TO AND CONTEXT OF HABERMAS'S RECENT VIEWS ON RELIGION IN THE PUBLIC SPHERE}

In this section we focus on the background to Habermas's ideas on religion in the public sphere and the context that caused him to revisit the old themes of reason and religion. Habermas's views on the rationalisation of society and culture in Western Europe form the intellectual background to his views on religion in the public sphere. In this section we also briefly refer to the new context of cultural and religious pluralism in the Western world that seemingly caused Habermas to revisit his views on the role of religion in the public sphere.

\section{A summary of Habermas's thinking on the rationalisation of society and culture}

Jürgen Habermas did not accept the diffused and sometimes irrational mixture of ideas in the new spirit of postmodernism. He did not resign himself to a presumed eclipse of the ideals of the Enlightenment and modernity. On the contrary, he has devoted his life-long thinking to the reinforcement of those ideals, including their philosophical foundation (cf. De Roest 1998:48). His new initiative, which is about saving the project of modernity and the secularization of European society, was based on his concept of communicative rationality (cf. Habermas 1982a, 1982b). Rationality in the lifeworld, where people are involved in discourse on validity claims and where communicative rationality operates, has to be distinguished from instrumental rationality. Communicative rationality forms part of Habermas's complex theory of communicative actions. The problem of rationality must simultaneously be handled on a meta-theoretical, methodological and empirical level (Habermas 1982a:20-24). Rationality is not only a faculty of the mind, positioned in a subject, but something that can be traced in acts of communication. This new insight was possible because Habermas moved away from the Kantian idea that reality is understood by subjective interpretations and concept formulation by individuals (Van de Beek 2006:24). He has appreciated the turn away from the paradigm of the subject to the paradigm of language - from the philosophy of consciousness to the philosophy of language, a communication-theoretical paradigm (cf. Habermas 1982a:28, 367-452). This approach does not start with the knowing subject who can relate herself or himself to the world, but with an intersubjectivity established through communication (Habermas 1985:421-438, 1993:47).

There is a close relationship between communicative rationality and the lifeworld or Lebenswelt (Habermas 1982a:107-113, 1993:90-108). The lifeworld is not only the background to the communication process, but also the source from which the participants can draw common understandings and values. The concept of lifeworld is thus complementary to the concept of communicative actions. Without the background of a shared lifeworld, discourses about validity claims (truth, rightness, truthfulness) are impossible (Habermas 1979:118-120). Habermas (1979) writes:

... the rationalizable aspect of communicative action has nothing to do with propositional truth; but it has everything to do with the truthfulness of intentional expressions and with the rightness of norms.

(Habermas 1979:119)

The rationality of communicative action, orientated to reaching understanding, is about a subject truthfully expressing his or her intentions in his or her actions, and with the validity claims connected with norms of action (Habermas 1979:119).

The rationalisation of a society occurs by means of learning processes. Human beings pass through a collective learning process that Habermas calls rationalisation. People cannot help learning when they disagree on norms and values in communication processes and in societal crises, especially when they do not understand each other. The mechanism of social development is to be found in the ability to learn (Habermas 1973:27-29, 1979:121, 1993:108-109). Reflexive learning is learning-in-discourse, which is a strong stimulation in the process of rationalisation.

Formale Gesichtspunkte für die Abgrenzung verschiedener Niveaus des Lernens ergeben sich aus dem Umstand, dass wir in zwei Dimensionen lernen (theoretisch/praktisch), und dass diese Lernprozesse mit Geltungsansprüchen verbunden sind, die diskursiv eingelöst werden können. [Formal criteria for distinguishing different levels of learning arising from the fact that we learn in two dimensions (i.e. theoretical or practical) and that these learning processes are connected with validity claims that can be redeemed discursively.]

(Habermas 1973:28)

Habermas (1979) compares the learning process of societies to the learning process of an individual's progress of developing from childhood to adulthood.

Individually acquired learning abilities' and information must be latently available in world views before they can be used in a socially significant way, that is, before they can be transposed into 'societal learning processes.

(Habermas 1979:121)

To trace the rationalisation processes in societies, Habermas uses the concept of reconstruction in the social sciences (cf. Habermas 1976:191-204). Societies pass through collective learning processes in human discourses from one level to another. The patterns of 
rationalisation can be reconstructed afterwards. Therefore, the mechanism of learning sets social developments in motion. The effect of communicative rationality in the rationalisation of the public domain in European societies can be reconstructed. Since Kant, ethical rationalisation has been pursued in his philosophy of religion, and it has also been pursued in modern theology (Habermas 1973:166-167). Habermas mentions theologians such as Pannenberg, Moltmann, Sölle and Metz and reflects on the role of Protestant ethics in the rationalisation of society (Habermas 1982a:299-331). Ethical rationalisation goes hand in hand with cognitive rationalisation.

The transition to modernity through the process of rationalisation has also transformed the importance of power in the structures of communication. Communicative rationality is liberated from force (De Roest 1998:127). This transition to modernity brought about the secularisation of European societies. Max Weber's concept of Entsauberung, in terms of which religion no more is the social cement of societies, has been vindicated (Habermas 1993:8, see also Habermas 1982a:262-298). Bernstein (1989:195) agrees with McCarthy (translator of many of Habermas's books into English) that Habermas's multifaceted investigations derive their unity from a vision of humankind, our history and its prospects. The interpretations that Habermas develops in all of his investigations of the interrelated contexts of development are animated by a unifying moral-political intention, the desire to show that there is a telos immanent in our communicative action that is oriented to mutual understanding.

The idea of communicative rationality that functions in the lifeworld of rational citizens who are free to find mutual understanding in communicative actions is endangered by the colonisation of the lifeworld by the systems of economy and politics (cf. Dreyer 1996:184-208). In order for this influence to be decreased, communicative rationality and communicative action are dependent on critical communities in which the debate about a just arrangement of society is kept alive (De Roest 1998:138).

These ideas are important, as they informed Habermas's earlier views on the role of religion in the public sphere. Mendieta (2002:1-36) provides a very good analysis of Habermas's ideas on religion in relation to the above core themes of his theory. He argues that we have to understand Habermas's view on religion as a continuation of the 'critical tradition of Jewish utopian messianism of the early Frankfurt School' (Mendieta 2002:2). It is not our aim to discuss Habermas's earlier views on religion in this article. The main point here is that Habermas's statements on religion as set out in his Theory of Communicative Action and The Philosophical Discourse of Modernity led to the view, in Mendieta's (2002) words,

that Habermas has put religion to rest, and has pronounced its theoretical and social-developmental death. In fact, a consensus has developed around the notion that Habermas's theory of the 'linguistification of the sacred' entails the sublimation or Aufhebung of religion tout court.

(Mendieta 2002:11)

\section{The new context of religious and cultural pluralism}

At the beginning of the 21st century, Habermas seemed to revise his position on the role of religion in the public sphere quite dramatically. This change in his views was so remarkable that many scholars paid attention to Habermas's new interest in religion (Cooke 2006, 2007; Harrington 2007a, 2007b; Lafont 2007). This renewed interest in religion can already be seen in Habermas's speech at the prize-giving function of the German Peace Prize Commission a month after the attacks of 11 September 2001, in which he dramatically concluded: 'Aber am 11 September ist die Spannung zwischen säkularer Gesellschaft und Religion auf eine ganz andere Weise explodiert' $[$ But on 11 September the tension between secular society and religion exploded in a different wayl (Habermas 2001:9). Habermas's interest in religion can also be seen in his book on the ethics of cloning,
The future of human nature (2001), his public dialogue with Joseph Ratzinger in January 2004 (Habermas \& Ratzinger 2007), and especially his book Zwischen Naturalismus und Religion (2005, English translation 2008) (Harrington 2007b:45). Harrington (2007b) even asks whether Habermas has made a theological turn in his thinking:

Since the turn of the millennium Jürgen Habermas has been increasingly writing about matters of religious and theological relevance.... In his most recent work, by contrast, Habermas offers a considerably more sympathetic engagement with the arguments of theologians and, at least on the surface, a dramatic self-distancing from his earlier secularist advocacy.

(Harrington 2007b:45)

Before we engage with some aspects of Habermas's recent views on the role of religion in the public sphere, we will reflect briefly on the context that seemingly caused Habermas to revisit the old themes of reason, religion and the public sphere. The terrorist attacks on the World Trade Center in New York and elsewhere in the USA on 11 September 2001 were a dramatic announcement of political religion motivated by religious fundamentalism. This phenomenon is not only a feature of the Middle East, but appears all over the world amongst Christians, Jews and Muslims, in the Near and the Far East, in Africa and, surprisingly, also in the United States of America (Habermas 2001:10-11, 2006:1-4). If we want to escape from a struggle between cultures and civilizations, we have to rethink the borders and the dialectic of religion and reason. Habermas set out to do so in Glauben und Wissen and in Zwischen Naturalismus und Religion, the titles of two of his recent books on this problem (Habermas 2001, 2005).

During the 1980s, we were told by some of our Dutch colleagues that the far-reaching secularisation in the Netherlands was just the forefront of a movement that would engulf many other countries. In the meantime, the global migration of peoples of different cultures, religions and worldviews was at full speed. The Netherlands, Germany, France and Britain, to name a few, are now experiencing the new plurality in full force (cf. Reader 2008). Therefore, a new multi-religious and multicultural context is created in modern, secularised European countries (Grözinger 2008:16). The new context of religious and cultural pluralism has been the reason for new thinking on the theme of religion and its place in the public sphere. And, as indicated above, Habermas has taken a philosophical lead in this new form of thinking (cf. his latest publications of 2001, 2005, 2006, and together with Joseph Ratzinger 2007).

Habermas's renewed interest in the role of religion in the public sphere can be seen as part of a general trend to recognise the role of religion in the public sphere that started in the early 1990s (Hackett 2005). Two factors in particular contributed to the new context of pluralism and the resultant new thinking on religion and the public sphere. Firstly, the economic and political changes that took place in Eastern Europe after the collapse of the Soviet Union resulted in a new experience of cultural and religious heritage, and was followed by conflicts (Danz 2007:9). Western Europe was suddenly confronted with different cultures and religions, and with the conflicts in Bosnia, Kosovo and Serbia.

A second factor was the worldwide migration of people due to economic globalisation. In the Western world, especially in Western Europe, people with different religions, cultures, ways of life and worldviews were mixing and living together with modern, secularised Europeans (Danz 2007:9). The conflict of civilizations meeting each other in the Western world was looming (cf. Huntington 2002). This religious and cultural pluralism has given rise to the question of how to deal with these different religious expressions and ways of life in a pluralistic context (Danz 2007:9).

It is in this context that Habermas refers to a post-secular society (Habermas 2001:13) and, following Peter Berger, mentions the desecularisation of the world as a major turn in our time (Habermas 2005:119). Habermas's views on the role of religion 
in the public sphere in a post-secular society are the subject of the next section.

\section{HABERMAS'S RECENT VIEWS ON RELIGION IN THE PUBLIC SPHERE}

In the previous section we argued that the new context of religious and cultural pluralism led Habermas to change his view on the importance of religion in the public sphere. Habermas's later works certainly show a renewed interest in religion. $\mathrm{He}$ also seems to be more prepared to acknowledge the role of religion in the public sphere than in the past. The question is how Habermas conceives the role of religion in the public sphere in these later works. But knowing that he is more open towards the public role of religion does not yet explain what this role is or should be. In this section we therefore explore Habermas's view of the role of religion in the public sphere in his later works, and in particular in the collection of essays published as 'Between naturalism and religion' (Habermas 2008).

In order to understand Habermas's new view of the role of religion in the public sphere, we first have to note that it is not an intellectual break with the past. We agree with Enn's (2007:893, n. 10) conclusion that 'Habermas does shift in allowing for greater input from religious beliefs but maintains the epistemic restrictions that ultimately undermine his project'. Furthermore, Habermas's new interest in religion is not in religion as such, but in the political role of religion. Habermas was not converted to Christianity or any other religion. In accordance with his theory of communicative rationality he is interested primarily in the cognitive potential of religion and in its contribution to a constitutional democracy and a democratic civil ethos. This is a continuation of his views on rationalisation, as discussed above. His renewed interest in religion is thus political and not religious.

In this section we briefly describe Habermas's recent views on religion in the public sphere, but in order to do so we first have to understand Habermas's view of the public sphere. This discussion is followed by a brief description of the conditions that Habermas set for religion to play a role in the public sphere.

\section{The political public sphere}

One of the enduring characteristics of Habermas's intellectual work is his engagement with and enduring interest in the 'public sphere'. In a recent article on the biographical roots of two motifs in his thought, Habermas (2008) wrote that

the public sphere as a space of reasoned communicative exchanges is the issue that has concerned me all my life. The conceptual triad of 'public space,' 'discourse,' and 'reason,' in fact, has dominated my work as a scholar and my political life.

(Habermas 2008:12-13)

Habermas (2008:11-12) distinguishes between two types of public sphere. The first is the public sphere as publicity. The important characteristic here is visibility. This is the public sphere of the media and the world of celebrities and sport stars. However, this is not the public sphere that is central in Habermas's thought. The second type of public sphere is the one referred to in the quotation above, namely that of 'reasoned communicative exchanges'. In this type of public sphere the spotlight does not fall on persons, but rather on opinions. It is this 'public sphere' where opinions are formed that concerns Habermas when he considers the role of religion in the public sphere. The subtitle of his chapter on religion in the public sphere, namely 'cognitive presuppositions for the "public use of reason" by religious and secular citizens', confirms this (Habermas 2008:114). Habermas's interest in religion in the public sphere is not in religion as a phenomenon, but in the contribution that religion can make to forming public opinion and the public will. Furthermore, Habermas is particularly interested in the political public sphere. His engagement with the public sphere is from the perspective of political processes and institutions, in particular the constitutional state. This engagement with the political also has biographical roots, as the young Habermas's ideas were shaped by the struggle to achieve democracy in postwar Germany. One of the key ideas that shaped his intellectual career was that only 'a vibrant and, where possible, discursive type of public opinion-formation' could lead to a change in political mentality and to the establishment of a democratic order (Habermas 2008:21).

In order to understand the role of religion in the (political) public sphere, we also have to note a very important distinction that Habermas makes between the 'wild' and the formal political public sphere (Habermas 2008:131). With the 'wild' political public sphere Habermas refers to the informal public sphere with its 'Babel of voices' and 'informal flows of public communication'. In contrast to the 'wild' political public sphere, the formal public sphere is institutionalised. It is the sphere in which political bodies operate. Although it also includes the preparliamentarian domain, the parliament is a supreme example of the formal political public sphere. The reason why Habermas regards this distinction as important in relation to the public role of religion will become clearer in the following section.

\section{Religion in the public sphere: the translation imperative}

We now turn to the heart of Habermas's recent views on the role of religion in the public sphere. Habermas has always considered religion to be an important source of morality. In his earlier work, however, he maintained that religion would lose its role through rationalisation processes, as we discussed above. Modern societies, he said, would outgrow the role of religion. Reason would be sufficient to ground morality. Habermas shared in the expectation of many intellectuals in the second half of the 20th century that the end result of the secularisation of European society and culture would be the end of all religious faith (Habermas 1982b:140). However, with the eclipse of the secularisation thesis this idea has lost its credibility. The continuing presence of religion, also in the public sphere, and the new context of religious and cultural pluralism that we discussed above, have forced Habermas to revise the role of religion in modern societies. The old distinction between 'traditional' and 'modern' societies can no longer be upheld (Habermas 2008:116). The turn in his thinking on the role of religion in the political public sphere thus centred on the continuing contribution of religion with regard to morality. Instead of seeing religion as something to be outgrown, Habermas (2008:131) now writes that religious traditions have a special power to articulate moral intuitions, especially with regard to vulnerable forms of communal life'. In contrast to his views in his earlier work, Habermas now recognises the enduring (cognitive) potential of religion in (post)modern societies (cf. Outhwaite 2009:161). Religion is not something that will be outgrown as a result of modernisation and rationalisation. Religion, based in the lifeworld of its participants, is an important and enduring source of morality. This contribution is particularly important, as religion gives a voice to the marginalised in society, to the 'vulnerable forms of communal life' (Habermas 2008:131). In this regard, Chambers (2007) concludes that

Habermas is not asking why the others, those religiously-minded people, still need religion; he is asking what he as an agnostic secularist can still get from religion... What he comes up with are essentially moral experiences that require a religious idiom to be fully expressed.

(Chambers 2007:220)

Habermas thus seems to make much more room for religion to contribute to the public sphere than in his earlier work. Religious traditions contain a semantic potential that could contribute to 'social solidarity' and 'normative awareness' (Habermas 2008:111) in modern democracies. Due to the colonisation of the lifeworld by the market and by administrative powers, every resource that could nurture this social solidarity and 
normative awareness should be conserved by the constitutional state (Habermas 2008:111). Habermas also writes that, despite examples to the contrary, churches and religious communities in well-established constitutional states generally contribute to the stability and advancement of a liberal political culture (Habermas 2008:124-125)

This 'revisionist perspective' does not mean, however, that Habermas accepts the role of religion in the public domain unconditionally. Habermas argues that religion should only be allowed to partake in opinion- and will-formation in the public sphere if certain conditions are met. Most importantly, religious consciousness has to be transformed to meet the cognitive challenges of a liberal, post-secular society. Habermas (2008:111) writes that religion has to renounce the claim to a monopoly on interpretation and to shape life as a whole'. Religious people have to accept that their worldview is not the only possible worldview. They have to exemplify certain cognitive conditions and corresponding epistemic attitudes (Habermas 2008:119) before they can participate in the public sphere from their religious perspectives. They also have to accept the separation of church and state, the neutrality of public institutions towards religious communities, and the public use of reason. They have to distinguish between their role as a member of a religious community and that of a citizen (Habermas 2008:112).

Habermas thus refers to cognitive learning processes, new epistemic attitudes, a postmetaphysical mode of thought, hermeneutical self-reflection and so forth in order for religious people to partake in the political public sphere. The most important condition that Habermas sets, however, is that religious ideas have to be translated into secular language that is a 'publicly intelligible language' (Habermas 2008:111-113) once the threshold from the wild public sphere is crossed into the formal (institutionalised) public sphere. In the words of Habermas (2008):

Religious traditions have a special power to articulate moral intuitions, especially with regard to vulnerable forms of communal life. In corresponding political debates, this potential makes religious speech into a serious vehicle for possible truth contents, which can then be translated from the vocabulary of a particular religious community into a generally accessible language. However, the institutional thresholds between the 'wild' political public sphere and the formal proceedings within political bodies also function as a filter that allows only secular contributions from the Babel of voices in the informal flows of public communication to pass through.

(Habermas 2008:131)

To summarise, only secular language that is in agreement with the 'public use of reason', that is equally accessible to all persons (Habermas 2008:120,122), can be allowed into the institutional public sphere. All traces of particularity of specific religions have to be filtered out:

In a constitutional state, only those political decisions can count as legitimate that can be impartially justified in the light of generally accessible reasons, in other words, that can be justified equally toward religious and nonreligious citizens and citizens of different confessions.

(Habermas 2008:122)

\section{HABERMAS'S RECENT VIEWS ON RELIGION IN THE PUBLIC SPHERE AND PUBLIC THEOLOGY}

We argued above that Habermas has shown greater openness towards religion in the public sphere because of the new context of religious and cultural pluralism. We also briefly described Habermas's revised view of the role of religion in the public sphere. The question now remains what Habermas's new view of religion in the public sphere could mean for theology, especially regarding its public dimensions. What can we learn from Habermas's recent views on religion in the public sphere? Do his recent views on this role create new possibilities for a public theology? What are the challenges for a public theology that Habermas puts on the table? In the following sections we will first briefly mention some of the critical points raised against Habermas's views. This is followed by a brief reflection on what we see as the possible contribution of Habermas's ideas to a public theology, despite the limitations of his theory.

\section{A critique of Habermas's recent views on religion in the public sphere}

Habermas's recent views on religion have been strongly challenged. It is not the focus of this article to give an overview of the critique of his work. We only mention two aspects that are particularly important for us, namely Habermas's lack of dealing with plurality and his very narrow understanding of religion. His critics are quick to point out that his ideas are framed within an extremely rational framework, a heritage of his continuation of the ideals of the Enlightenment. In the end he does not really succeed to deal with the 'Other', despite the fact that his renewed interest in religion is partly due to the presence of 'the Other', as we indicated above. Harrington (2007b), for example, concludes as follows after his extensive review of Habermas's latest work on religion:

One might say that in its will to 'include the other', Habermas's thinking about religion has a paradoxical tendency to perform the thing it most seeks to avoid, namely to exclude the 'Other' or to exclude otherness. Its problem is that precisely in its will to universal accommodation, it may only end by immunizing itself against a challenge from something more profoundly outside of itself. Only when his thinking regains a commitment to expose itself to something more one-sided, to something more dangerously particularistic, decisive or excessive - perhaps with the consequence of failing, disappointing or even antagonizing certain people or parties - only then, one might suggest, will it have a chance of acceding to the universality it so passionately desires.

(Harrington 2007b:59)

A second major critique of Habermas is his very limited and idealised view of religion. He focuses on the rational aspects of religion, but this is a very 'thin' view of religion. Religion is much more than morality and cognitive content. Important aspects of any living religion, such as community, experience, tradition and ritual, are filtered out by his approach, with only a very rational view of religion that remains behind (cf. Braeckman 2009). Adams (2006:49) writes in this regard that Habermas is not really interested in religious life and thought for their own sake, nor in the 'messy particularities' of different religious traditions. Again we see how his preoccupation with a universal rationality leads him to ignore particularity, contextuality and the role of particular traditions.

\section{The possible contribution of Habermas's recent views on religion in the public sphere to a public theology}

Despite the above important points of criticism, we are of the view that Habermas has important contributions to make to public theology. The focus of this section is not so much on the limitations of his ideas, but rather on the possible contribution of Habermas's ideas to an understanding of the tasks and role of public theology. What can we learn from Habermas's recent views on religion in the public sphere? What challenges to public theology can be deduced from his work on religion in the public sphere? We will touch only briefly on these aspects.

\section{The importance of communicative rationality}

Religion should find a forum where a real, critical, cognitive debate on the issues raised by Habermas could thrive. That forum could be the centres of public theology such as those at the Universities of Pretoria and Stellenbosch. An important task of these centres of public theology could be to foster hermeneutical self-reflection and critical debate. Secular participants from the public sphere could be invited to participate in these debates. The issue of communicative rationality also challenges religious 
people to distinguish between different roles - acting as a member of a religious community and, on occasions of public debate, acting as a citizen.

\section{Lifeworld and social solidarity}

It is important that public theology should have a connection with the lifeworld. We differ here from Habermas in the sense that we must make room for the experiences and understanding of the lifeworld of different religious traditions in the discourses in the public sphere. Participants from different religious traditions can share ideas with participants from other (political) institutions on problems, projects on the ground, and the ideas and hopes of citizens who are in need. Religious institutions such as churches are busy with an immense task in South Africa regarding social solidarity and caring for the vulnerable. Through its centres of public theology, religion should bring to discussions in the public sphere its passion, mission, work and experience of social solidarity, and its caring for the vulnerable in society. This has always been the core of public theology. Habermas has an eye for this notion.

\section{No religious claim to a monopoly of worldview}

If we, as religious people representing the churches, want to join the public debate on the burning issues in South African society, we have to accept our secular state - our constitution with its liberal values of a modern state, and renounce any claim to a monopoly on the interpretation of reality, in the sense that we must leave the idea behind that we can only go into discussions with secular citizens with our own worldview as a premise. We have to come to a common understanding on how to operate in the role of members of a religious community and as citizens operating in the public sphere.

Habermas has challenged religion to translate our 'moral intuitions' into secular concepts and into language that can equip us to debate on an equal level with secular (political) society. This translation imperative is a major challenge for public theology. It raises the questions of what must be translated, how must it be translated, etc. This issue is so complex that we cannot address it here in full. In some aspects it is impossible to comply with Habermas's condition of translation. We will have to discuss this issue in depth in our public theology forums.

The above ideas open up a much greater role and vision for the centres of public theology at our theological faculties and for our connections with such international centres.

\section{Habermas's openness to religion in public debate}

Habermas's openness to the rational potential of religion is certainly positive. We agree with Habermas that religion in general, and our Christian tradition in particular, contains resources that could contribute to rational discussions in the public sphere. This is the basic point of departure for any public theology. Habermas challenges public theologians from all theological disciplines to be clear on the rational suppositions of their arguments. We certainly have to learn how to take part in discourses in a civil, rational manner. The time has past when theologians could enter public debates from a position of superiority or from a position of faith-based claims. The challenge is to go through the learning processes, to take rationalisation seriously. The French philosopher Paul Ricoeur writes in this regard, and particularly about the importance of integrating a critical dimension within religion: 'It is very characteristic of Judaism and of Christianity that they ultimately performed the difficult marriage of conviction and critique...' (Ricoeur 1998:133). This is an important part of the learning process, and of rationalisation.

How do we evaluate the translation imperative that Habermas sets as a condition for religion to participate in the discourses in the public sphere? This idea of translating religious ideas into a secular language is not something new for public theologians.
Many public theologians have set this requirement for public theology. Kim (2007:1) writes in the editorial of the first edition of the International Journal of Public Theology: 'Public theology is a deliberate use of common language in a commitment to influence public decision-making, and also to learn from substantive public discourse.' Two examples from our South African context can also be mentioned in this regard. De Villiers (2005) writes:

The crucial question with regard to the effective promulgation of the Christian vision of a good South African society is: Should it be promulgated in the broader South African society in its distinctively Christian form, or is some translation of it needed to ensure its wider acceptance?

(De Villiers 2005:530)

De Gruchy (2007:39-40) formulated seven theses for public theological praxis. His second thesis is that

good public theological praxis requires the development of a language that is accessible to people outside the Christian tradition, and is convincing in its own right; but it also needs to address Christian congregations in a language whereby public debates are related to the traditions of faith.

(De Gruchy 2007:39)

The question is thus not whether we have to translate our religious ideas into secular language, but how this is to be done. Habermas's translation imperative filters so much of religion and religious life that we are eventually left with a very rational approach to religion. Here we would rather follow Ricoeur, who pleads for keeping the balance between critique and conviction (Ricoeur 1998).

This focus on the cognitive potential of religion in the public sphere is a typical liberal response to the problem of religion in the public sphere (Chatterjee 2006:59). In his discussion of Talal Asad's contribution to the debate on secularisation, Chatterjee (2006) says that this liberal response only allows for a particular kind of religion to participate in the public sphere:

The new claim that religious movements and parties may well have a legitimate place in modern politics 'if' they agree to confine themselves to rational debate and persuasion and not resort to intolerant and violent methods is, he shows, only a plea for a 'particular kind' of religion.

(Chatterjee 2006:59)

The secular paradigm actually forces religion to reform and to adapt to the secular world, rather than the other way round (Chatterjee 2006:60). Another problem is that this model of the secular state, in which religion is seen as an 'intrusion' into politics and public life, is not a universal model. In many parts of the world, especially in Africa and Asia, this view of religion and politics 'represents a normative project rather than a set of actually existing practices' (Chatterjee 2006:61). It is also important to note that even where this liberal idea of the rational contribution of religion is accepted, we see that religion is used in non-rational ways for propaganda purposes or to mobilise people on the basis of their desires and anxieties (Chatterjee 2006:59). The role of religion in the public sphere thus has to be seen in all its 'messiness', as it is in practice entangled in power games and coercive strategies. We will have to ponder the question: what are the implications of this for a public theology? We therefore also need to consider the differentiated thinking about 'public' (cf. Bezuidenhout \& Naudé 2002).

\section{CONCLUSION}

Habermas certainly is more open to the contribution of religion in modern, constitutional states in his recent writings. He seems to accept that religion is not some kind of remnant from the past that will disappear because of modernisation and rationalisation processes. Despite the limitations mentioned we can conclude that public theology has much to learn from Habermas's latest work and the challenges that he poses regarding the role of religion in the public sphere. 


\section{REFERENCES}

Adams, N., 2006, Habermas and theology, Cambridge University Press, Cambridge.

Bernstein, R.J., 1989, Beyond objectivism and relativism, Basil Blackwell, Oxford.

Bezuidenhout, R. \& Naudé, P., 2002, 'Some thoughts on "public theology" and its relevance for the South African context', Scriptura 79, 3-13.

Bosch, D.J., 1991, Transforming mission: paradigm shifts in theology of mission, Orbis, Maryknoll, NY.

Braeckman, A., 2009, 'Habermas and Gauchet on religion in postsecular society. A critical assessment', Continental Philosophy Review 42, 279-296.

Calhoun, C., 1992, 'Introduction: Habermas and the public sphere', in C. Calhoun (ed.), Habermas and the public sphere, pp. 1-48, MIT Press, Cambridge, MA.

Casanova, J., 1994, Public religions in the modern world, University of Chicago Press, Chicago.

Chambers, S., 2007, 'How religion speaks to the agnostic: Habermas on the persistent value of religion', Constellations 14(2), 210-223.

Chatterjee, P., 2006, 'Fasting for Bin Laden: the politics of secularization in contemporary India', in D. Scott \& C. Hirschkind (eds.), Powers of the secular modern: Talal Asad and his interlocuters, pp. 57-74, Stanford University Press, Stanford, CA.

Cooke, M., 2006, 'Salvaging and secularizing the semantic contents of religion: the limitations of Habermas's postmetaphysical proposal', International Journal for Philosophy of Religion 60, 187-207.

Cooke, M., 2007, 'A secular state for a postsecular society? Postmetaphysical political theory and the place of religion', Constellations 14(2), 224-238.

Danz, C., 2007, 'Religion zwischen Aneignung und Kritik. Überlegungen zur Religionstheorie von Jürgen Habermas [Religion between appropriation and criticism. Reflections on the religion theory of Jürgen Habermas]', in R. Langthaler \& H. Nagl-Docekal (Hrsg.), Glauben und Wissen. Ein Symposium mit Jürgen Habermas, pp. 9-31, R. Oldenbourg Verlag, Wien.

De Gruchy, J., 2007, 'Public theology as Christian witness: exploring the genre', International Journal of Public Theology 1, 26-41.

De Roest, H., 1998, Communicative identity. Habermas' perspectives of discourse as a support for practical theology, Kok, Kampen.

De Villiers, E., 2005, 'The vocation of reformed ethicist in the present South African society', Scriptura 89(2), 521-535.

Dekker, G., Luidens, D.A. \& Rice, R.R. (eds.), 1997, Rethinking secularization. Reformed reactions to modernity, University Press of America, Lanham/New York/London.

Dreyer, J.S., 1996, 'Habermas se kolonialiseringstese en 'n prakties-teologiese ekklesiologie [Habermas's colonisation thesis and a practical-theological ecclesiology]', in $\mathrm{M}$. Nel (red.), Prediking. Kommunikasie in konteks, pp. 184-208, Makro Boeke, Pretoria.

Enns, P., 2007, 'Habermas, reason, and the problem of religion: the role of religion in the public sphere', Heythrop Journal 48(6), 878-894.

Grözinger, A., 2008, Homiletik [Homiletics], Lehrbuch Praktische Theologie Band 2, Gütersloher Verlagshaus, Gütersloh/ München.

Habermas, J., 1973, Legitimationsprobleme im Spätkapitalismus [Legitimation crisis in late capitalism crisis], Suhrkamp, Frankfurt am Main.

Habermas, J., 1976, Was heisst Universalpragmatiek? [What does universal pragmatics mean?], in K.-O. Apel (Hrsg.), Sprachpragmatik und Philosophie, pp. 174-272, Suhrkamp, Frankfurt am Main.

Habermas, J., 1979, Communication and the evolution of society, transl. T. McCarthy, Heinemann, London.

Habermas, J., 1982a, Theorie des kommunikativen Handelns I. Handlungsrationalität und gesellschaftliche Rationalisierung, Zweite Auflage, Suhrkamp, Frankfurt am Main. (English translation, 1984. The theory of communicative action. Reason and the rationalization of society, Beacon Press, Boston).
Habermas, J., 1982b, Zweite Auflage. Theorie des kommunikativen Handelns II. Zur Kritik der funktionalistischen Vernunft, Suhrkamp, Frankfurt am Main. (English translation of Volume II, 1989, The theory of communicative action. Lifeworld and system: a critique of functionalist reason, Beacon Press, Boston).

Habermas, J., 1985, Zur Logik der Sozialwissenschaften [On the logic of the social sciences], Suhrkamp, Frankfurt am Main.

Habermas, J., 1989, The structural transformation of the public sphere, transl. T. Burger \& F. Lawrence, MIT Press, Cambridge, MA.

Habermas, J., 1993, Na-metafysisch denken [Post-metaphysical thinking], Kok Agora, Kampen/Pelckmans, Kapellen.

Habermas, J., 2001, Glauben und Wissen. Friedenspreis des Deutschen Buchhandels 2001 [Faith and knowledge. Peace Prize of the German book Trade in 2001], Suhrkamp, Frankfurt am Main.

Habermas, J., 2005, Zwischen Naturalismus and Religion. Philosophische Aufsätze [Between Naturalism and Religion. Philosophical essays], Suhrkamp, Frankfurt am Mai.

Habermas, J., 2006, 'Religion in the public sphere', European Journal of Philosophy 14(1), 1-25.

Habermas, J., 2008, Between naturalism and religion. Philosophical essays, transl. C. Cronin, Polity Press, Cambridge. (English translation of Zwischen Naturalismus and Religion. Philosophische Aufsätze.)

Habermas, J. \& Ratzinger, J., 2007, Dialektik der Säkularisierung. Über Vernunft und Religion [Dialectic of secularization. About Reason and Religion] Auflage 7, Herder, FreiburgBasel-Wien.

Hackett, R.I.J., 2005, 'Rethinking the role of religion in changing public spheres: some comparative perspectives', Brigham Young University Law Review 3, 659-682, viewed 04 February 2010, from http://lawreview.byu.edu/ archives/2005/3/5HACKETT.FIN.pdf

Harrington, A., 2007a, 'Habermas and the "Post-Secular Society"', European Journal of Social Theory 10(4), 543-560.

Harrington, A., 2007b, 'Habermas's theological turn?', Journal for the Theory of Social Behaviour 37(1), 45-61.

Huntington, S., 2002, The clash of civilizations and the making of the world order, Free Press, London.

Joas, H., 2009, 'Does modernisation lead to secularisation?' in W. Gräb \& L. Charbonnier (eds.), Secularization theories, religious identity and practical theology, pp. 25-34, Lit Verlag, Münster.

Jonker, W., 2008, Die relevansie van die kerk. Teologiese reaksies op die betekenis van die kerk in die werreld [The relevance of the church. Theological reactions to the meaning of the church in the world], Bybel-Media, Wellington.

Kim, S., 2007, 'Editorial', International Journal of Public Theology $1,1-4$.

Lafont, C., 2007, 'Religion in the public sphere: remarks on Habermas's conception of public deliberation in postsecular societies', Constellations 14(2), 239-259.

Mendieta, E., 2002,'Introduction', in J. Habermas (ed.) and with an introduction by E. Mendieta, Religion and rationality. Essays on reason, God, and modernity, pp. 1-36, Polity Press, Cambridge.

Mooney, M., 2006, 'The Catholic Bishops Conferences of the United States and France: engaging immigration as a public issue', American Behavioral Scientist 49(11), 1455-1470.

Outhwaite, W., 2009, Habermas: A critical introduction, 2nd edn., Polity Press, Cambridge.

Reader, J., 2008, Reconstructing practical theology. The impact of globalization, Ashgate, Abingdon/Alderslot.

Ricoeur, P., 1998, Critique and conviction. Conversations with Francois Azouvi and Marc de Launay, transl. K. Blamey, Polity Press, Cambridge.

Taylor, C., 2007, A secular age, The Belknap Press of Harvard University Press, Cambridge, MA.

To, C.-Y. \& Tulasiewicz, W., 1993, 'Conclusion' in W. Tulasiewicz \& C.-Y. To (eds.), World religions and educational practice, n.p., Cassell, New York.

Van de Beek, A., 2006, Van Kant tot Kuitert [From Kant to Kuitert], Kok, Kampen. 